44-DEC. 8, DAILY TRADE RECORD: An important textile authority is quoted as follows: "The first real flag of distress has been hoisted in the dyestuff situation. This has been the withdrawai from the market of al lines of denims manufactured by the two largest denim mills of the country. These mills state that present orders will exhaust their supplies of dyestuffs and they have no means of replenishing. These two great mills have about two months work ahead and will then probably have to shut down

"The average retailer in this country appears to have a very faint comprehension of the critical situation in dyestuffs. He was told the story of the danger of cutting off of supplies at the very outbreak of the war. He was urged by the selling agents of the mils to stock up with this line and that of colored goods on the theory that there would be a famine in prints and other colored lines within a few weeks' time. But these jobber's and retailers have found themselves steadily able for four months, to buy all they wanted, and they have naturally assumed that this tale of woe wa simply another device of clever salesmen to tempt them into placing large forward orders.

"And the curious fact is that in many lines of colored goods today, the very dyes of which the mills are most acutely short, are represented by manufactured stocks of goods on hand of which they have the largest supply. This fact will tend to postpone still further the general recognition of the dye famine which the mills are forcing."

45-Dec. 9, Darly Trade ReCord: At a meeting of the Dyestuffis Committee of the National Association of Finishers of Cotton Fabrics, held prior to the general meeting of the association, at the Arkwright Club yesterday, the proposed convention of users and producers of dyestuffs was discussed, and it was decided for the present that the matter would not be pushed. The committee is well aware of the serious shortage of dyestuffs, but does not feel that the shoe has yet pinched hard enough to bring it home to consumers. The responses to the circular letter sent out by Secretary Danner, to users and producers of dyestuffs, asking if they favored sending delegates to a geteral convention, were disappointing to the committee, and showed that the time was not opportune for a general convention.

46--DEC. 9, DAILY TRADE RECORD: The Glenlyon Dye Works, of Saylesville, R. I., are reported to have resumed the use of colors which were withdrawn several months ago, when the dyestuffs shortage first became acute. The Glenlyon is said to be in a position to put out its full line o yarn dyes again. J. G. Whitaker, manager of the Glenlyon works, is quoted as saying that the supply of fast dyes which the concern now has should last from four to six months, according to the demand of the trade... There has been a heavy curtailment among colored goods manufacturers, both it the East and South, for some weeks past. This curtailment is stil in evidence. It has been due partially to lack of orders for goods and partially to the shortage of dyestuffs. Manufacturers and finishers do not hesitate to say that if there was a normal demand for goods, the supplies for dyestuffs on hand would be cleaned up within a few weeks.

47-DEc, 10, Jourval of Commerce: If they (the buyers) really show a need for goods and will place orders on which mills cat predicate plans of future operations to the extent of stocks or dyestuffs on hand, it is thought quite possible that agents will make a revision that will meet imtnediate conditions. .... The fact that the largest printers are operating less than half their machinery is its own answer to the crisis in the dyestuffs situation with them. There are some of the large jobbing house buyers who are now very anxious concerning certain colored goods they will need for Spring. During the past week agents have had reason to know that buyers no longer regard the dyestuffs shortage as something to joke about.

48-Dec. 12, 1914, TextILE Manufacturitrs' Journal: Stocks STFADIIX DEPIETED, SUPPLY OF COLORS WANTED GROWS CONSTANTIY SMALLER. ....... DYESTUFF SUPPLY SMALL. CONSUMERS NOT OPTIMISTIC ABOUT FUTCRE DEVEIOPMENTS.

49-DEC. 30, NEW YORE TMRS: wIL DYES Hold our? Factors in the piece goods market are rather puzzled over what the dyestuff shortage will mean during the coming heavyweight season. The tremendous anount of dyes required in filling the contracts let out here for army cloths will seriously deplete the small stocks of dyes on hand.

50-TAN, 9, 'TEXTILE MANCFACTURERS' JOURNAT: The situation in some of our dyestuffs is desperate. There is no gainsaying it, and it behooves us to look the facts in the face and not squander time, which we could put to much better uses, in vain regrets and recriminations that our supply houses had not foreseen contingencies as they have happened and provided an unlimited stock of the colors which we need.

It is to be expected that Anerican dyestuffs makers will largely benefit by these circumstances; but, on the other hand, it is doubtful whether they will have the courage of enlarging to such an enormous extent as to be able to meet the European deficit, since they must figure upon the probability that when peace is again established the Europeans will make every effort to regain the profitable American field.

BLEACHING SUBSTITUTE FOR DYEING-This leaves a clear-cut issue before us textile manufacturers: What we have not got we cannot make use of and our commission merchants and jobbers and stores cannot sell. The public will then be forced to content itself with undyed goods, but this does not mean the raw, woven or knitted fibers, which would be too unsightly for wear. We can beautify them immensely by bleaching, and this will be the solution of our problem and the salvation of our textile industries. As long as we have white goods to wear we shall always be able to clothe ourselves in good taste.

51-Jan. 20, Journal OF COMMERCE: Theodore Boettger, of the United Piece Dye Works of Lodi, N. J., the largest dyers of textile in the piece, told the members of the Jobbers' Association of Dress Fabric Buyers yesterday afternoon, who were holding their annual convention at the Waldorf-Astoria, that the scarcity of dyestuffs on account of the war, was not serious, although a scarcity really exists. The buyers of dress goods, Mr. Boettger said, conld go ahead and conduct their business without interruption. At any rate, he said, they could let the dyers do the worrying.

52-FeB. 20, TeXTile Manufacturgrs' Journal: So far little if any machinery has had to shut down on account of inability to obtain dyes, but any reserve stock, either in manufacturers' or importers' warehouses, has absolutely disappeared.

90 WILliam STREET, NEW YORK City

\title{
COMPULSORY WORKING OF PATENTS IN THE UNITED STATES, GERMANY AND GREAT BRITAIN'
}

\section{BY BERNHARD C. HESSE}

The United States Patent Act of July I3, 1832, for compulsory working of patents reads as follows:

“AN ACT CONCERNING THE ISSUING OF PATENTS TO ALIENS, FOR USEFLL DISCOVERIES AND INVENTIONS"

"Be it enacted by the Senate and House of Representatives of the Cnited States of America in Congress assembled; That the privileges granted to the aliens described in the first section of the Act, to extend the privilege of obtaining patents for useful discoveries and inventions to certain persons therein mentioned, and to enlarge and define the penalties for violating the rights of patentees, approved April seventeenth, eighteen hundred, be extended in like manner to every alien who, at the time of petitioning for a patent, shall be resident in the United States, and shall have declared his intention, according to law, to become a citizen thereof: Provided, That every patent granted by virtue of this Act and the privileges thereto appertaining, shall cease and determine and become absolutely void without resort to any legal process to annul or cancel the same in case of a

: Received March 1, 1915 failure on the part of any patentee, for the space of one year from the issuing thereof, to introduce into public use in the United States the invention or improvement for which the patent shall be issued; or in case the same for any period of six months after such introduction shall not continue to be publicly used and applied in the United States, or in case of failure to become a citizen of the United States, agreeably to notice given at the earliest period within which he shall be entitled to become a citizen of the United States."

That part of this Act preceding the proviso was introduced into the House of Representatives January 6, I 832 ; then it went to the Senate and there the proviso was added; then accepted by the House and finally approved by the President.

This Act was repealed $\mathrm{J} u 1 y$ 4, 1836 . No such compulsory provision has since been placed on our statute books.

Precisely why this Act should have been passed and then repealed is not now determinable since a thorough search through the records of Congress does not disclose any debate nor any committee report; my information is that in those days Senate 
proceedings were secret and records were not kept; detailed committee reports on patents do not begin until 1837 ; the House record merely notes introduction, the acts of reading and of passing.

\section{GERMAN WORKING CLAUSE}

Dr. C. Wiegand, of Berlin, in a paper entitled "Compulsory Working and Compulsory Licenses" published at p. I 88 of the "Transactions of the International Association for the Protection of Industrial Property," for the meeting of June, IgI2, says of the German Compulsory Working Act of June 6, IgII: "Under the provisions of the previously existing law a patent could be revoked, if the invention was not worked to a sufficient degree within the country, or at any rate everything done to secure this working. Opposition to this unconditional compulsory working was made by numerous mantufacturers and lawyers, and as established by the arguments in support of the Law of June 6, I II , it was shown that the system of compulsory working in itself led to an uneconomical splitting up of the source of production and that consequently the abolition of compulsory working was to be desired. The Imperial Government adopted this view in principle, but pointed out that so long as other important manufacturing countries, in which the German industries and German applicants for patents had important interests, retained their compulsory working provisions or introduced them afresh, a general abolition of compulsory working in Germany was not to be recommended. On the other hand, in all cases where another State was ready to accord the same benefit to German inventors, compulsory working should be abolished as against this State by treaty.

"There exist between Germany on the one hand and the United States, Switzerland and Italy on the other hand, treaties by which the subjects or citizens of these States, either generally or under particular conditions, are not subjected to the compulsory working provisions. The German Government, which in this matter sees eye to eye with the greater part of the German industry, is anxious to proceed further on the same lines and to abolish compulsory working by treaty with other important industrial countries."

The relevant and essential text of the German working clause of June 6, I9 I I, is given, in translation, as follows by Dr. Wiegand (Loc. cit.): "If the patentee refuses to another the permission to use the invention when offered remuneration and guarantee, the right to use the invention can be accorded (compulsory license) to the other person, if the grant of this permission is demanded in the public interest. The right to use the invention can be granted with limitations and be made dependent upon conditions.

"The patent can be revoked provided State treaties do not prevent this if the invention is exclusively or mainly worked outside the German Empire or the Protectorates. The assignment of the patent to another is without effect if it has only the object of avoiding revocation.

"Before the expiration of three years after the publication of grant of the patent, no decision can be rendered against the patentee."

\section{BRITISH WORKING CLAUSE}

In I 907 the British Parliament enacted a compulsory working clause. The following excerpts from the Journal of the Royal Society of Arts for 1908 and onwards show how the effects of that enactment were regarded.

Vol. 56, p. I43 (Jan. 3, I908): "The new patent law requiring the production of patented articles in English works is having the anticipated effect in bringing German color manufacturers to this country."

Vol. 56, pp. 283-4 (Jan. 3I, I g08): "It is seldom that an Act of Parliament has such an immediate and beneficial effect as that which seems likely to follow upon the coming into operation of the New Patent Act. Many foreign patentees are already negotiating with British manufacturers to carry out in the United Kingdom their British patents. Others have taken land for the purpose of erecting works in order themselves to work their British manufacturers. ........

"A well-known American company which holds British patents for the manufacture of safety razors, hitherto made solely in the States, have secured land in Sheffield, and expect to employ 500 hands as soon as their works are completed. Many other foreign manufacturers holding British patents, which they have hitherto worked solely abroad, are following their example. There is not the slightest doubt, writes.Mr. Ivan Levinstein, in an interesting letter directing attention to what the new Act has already brought about, that the advent of these foreign manufacturers will mean additional employment for workersthe operative classes, highly trained engineers and chemistsand give a new impetus to British enterprise.' Unlike its predecessor, the new Act is clearly worded, and leaves no loopholes for escape from its salutary and much-needed provisions."

Vol. 56, pp. 924-5 (Sept. 4, I908): "This Act, the Patents and Designs Act, became operative on August 28 th. Its principal clause runs as follows: 'At any time, not less than one year after the passing of this Act, any person may apply to the Comptroller for the revocation of the patent, on the ground that the patented article or process is manufactured or carried on exclusively or mainly outside the United Kingdom.' In future, foreign manufacturers, if they wish their patents to remain valid in Great Britain, will have to make the goods they sell within the United Kingdom. Otherwise their patents may be copied or infringed at will. Germany and the United States are particularly hit by the new enactment, and they are meeting the altered conditions by ( $I$ ) building factories of their own in England; (2) acquiring premises already built for the purpose of carrying on their business; (3) arranging with British manufacturers to lay down plant and coopperate in the production of the special articles which are the subject of the patent. Already some thirty foreign firms-many of them conducting operations on a large scale-have begun, or are about to begin operations in this country, most of them choosing the North of England as the scene of their operations. It is said that as a rule the foreign manufacturer is providing a factory many times larger than is really necessary for the construction of his patented article, his explanation being that he cannot run works in England on patents alone, and he intends therefore to manufacture in this country goods that have hitherto been imported readymade. So far as can be seen at present the Act must profit British labor. It is said in some quarters that these manufacturers, at any rate the German ones, will be worked by foreign staffs, but this is not the case at present with Messrs. Meister, Lucius, and Bruening (Limited) of Germany, a company with a capital of $£_{I I, 000,000 \text {, which has just erected a new chemical }}$ factory at Ellesmere Port. Here all the workers employed are English, with the exception of a few German overseers. The working of the Act will be watched with keen and anxious attention, for British manufacturers are beginning to realize that foreign competition is about to invade their own particular territory, and that there will be a fair but strenuous fight on British soil for British custom. That is not a prospect that can be viewed altogether with anxiety when the perfection of German organization is remembered. The German things to be manufactured in England will be mostly aniline dyes, pottery, plant for gas making, rifles, plated goods, electrical contrivances, furnaces, sanitary appliances; the American, typewriters, safety razors, phonograph records, shoes, telephones, and wire roofing."

Vol. 56, p. 952 (Sept. 18, 1908): "It is seldom that an Act of Parliament works quite as its authors and supporters hoped and expected. The Trade Marks Act is one of the most striking illustrations of this truth. It may be that the New Patents Act will be another. It may bring the foreign competitor to even 
closer grips than at present with our manufacturers, and it may lead the inventor to resort more frequently to the secret process.....

"Independent discovery is now the only risk menacing a monopoly based on secret working, and the risk of independent discovery is usually not great; it is at least much smaller than that consequent upon betrayal or accident. It is quite possible, therefore, that one of the results of the Patent and Designs Act 1907, will be largely to increase the number of inventions worked as secret processes."

Vol. 57, p. 212 (Jan, 29, x909): "There has been some recent correspondence in the Times as to the probable effect of the revocation of certain patents on the ground of their not having been worked in the United Kingdom. The section was intended to encourage British industries, and was indeed welcomed as a Protectionist measure by the opponents of Free Trade. It is now urged that its probable result will be to encourage the manufacture of the patented article abroad and its importation into this country, it being improbable that manufacturers here will find it pays to produce it if the manufacture is unprotected by a patent. Thus the clause may now conscientiously be approved by Free Traders. Attention has also been drawn to the remarks made by the Comptroller, who, in delivering his judgment expressed the opinion that it was to the general advantage that the trade should be freed and the importer enabled to obtain the foreign manufactured goods readily. This doctrine, if carried to its legitimate conclusion, would seem to justify the abolition of patents entirely, and the revocation, not of an occasional patent, but of the Statute of Monopolies itself."

Vol. 57, p. 340 (March 6, 1909): "The great advantages to this country attendant upon the passing of the Patents and Designs Act, I907, have not, so far, been sufficiently appreciated by manufacturers and merchants in the United Kingdom."

Vol. 58, p. 473 (March I8, 1910): "The expectation that the Patents Act of three years ago would result in foreign firms acquiring land and erecting buildings in this country to a considerable extent has already been verified. The Act came into force on January $I, 1908$, and since then foreign firms have acquired land in England to the value of $£ 188,650$, and they have spent $£_{290,750}$ in the erection of buildings and the housing of their work-people, and a further sum of $£_{410,972}$ on plant, machinery and equipment. Thus in two years the Act has caused foreign firms to spend $£ 890,372$ in this country. $\mathrm{Mr}$. Farmer, of Messrs. Leopold Farmer and Sons, who has given special attention to the subject, says that the Americans, Germans, Dutchmen, Frenchmen and Swedes have taken part in this commercial invasion, and he estimates that over forty firms are represented. Among them are manufacturers of matches, electrical apparatus, chemicals, pottery, pencils, mercerized cotton goods, musical instruments, roofing felt, incandescent gas mantles and rubber goods, all compelled by the Patent Act to make their goods in this country, to buy land, build factories, employ home labor, and pay rates and taxes. The works are scattered all over the country. They are in the metropolitan area, Middlesex, Kent, and Essex. In Cheshire several firms have established works on the Mersey; others are at Leicester bootmaking; others again at Warrington, Wolverhampton, in South Wales and Yorkshire. According to official figures some 8,000 people are employed as the result of the Act, mostly men, and the local authorities will benefit in the shape of rates substantially."

The accuracy and dependability of these statements is probably not very great. For instance, the combined capital of three German dye companies is given at $260,000,000$ Marks and of two others at I60,000,000 Marks or 420,000,000 Marks for these 5 German dye companies. On June 30 , IgI2 the 2 I German dye plants, inclusive of these five, had a combined total capital of 146,800,000 Marks. That is, the Journal of the Royal
Society of Arts attributes three times as much capital to 5 plants as all 2 I had together almost 4 years later; the German dyecompanies have progressively increased their combined capital stock and have not decreased it.

The following tabulation shows four different estimates of fresh capital invested in Great Britain as a result of this Act:

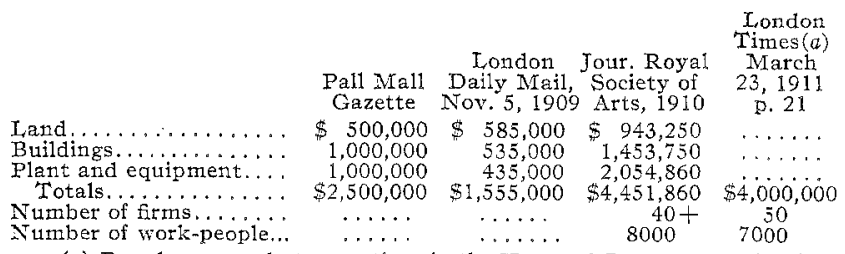
Number of work-people...

(a) Based upon reply to questions in the House of Commons at the close of 1909 , made by the President of the Board of Trade; there are no official

In spite of much searching in Washington and New York I have been so far unable to locate any item-by-item statement for any of these lists. No doubt such lists exist but so far they have succeeded in escaping me.

I quote from private letters to me (B. C. FI.) from England by a friend of over nineteen years' standing and dated February 8 and I2, I9I5, after, for obvious reasons, having made certain indicated omissions and corresponding textual changes:

"Questions have been asked in Parliament once or twice, and I followed the answers with interest but they were purposely very vague, and gave no real information, but put the effect of the working clauses as great as possible in a vague way.

"A firm of estate agents, Farmer and Company, who did do a little business in selling land or a factory to people coming over here to work patents made the most of the Act and wrote to the papers with reference to it, thereby getting a free advertisement. They published tables, showing the effect of the Act, which were grossly misleading; for instance one factory appeared four times in the list with the nominal capital so that the capital was quadrupled. Again the number of work-people to be employed by it was estimated at 400 , and this given four times made $x, 600$, instead of 37 . Precisely the same sort of thing was done with reference to any other factory as to which I know anything. I cannot say whether the list was more accurate about factories of which I know nothing, but in any case these lists were absolutely worthless. The way in which this factory was given four times was this. It was given at first under the proper name-Chemical Works. Then it was given as a factory to be erected by Company A, a factory to be erected by Company $\mathrm{B}$, and a factory to be erected by Company $\mathrm{C}$. (Note: $\mathrm{A}, \mathrm{B}$ and $\mathrm{C}$ companies together erected this one plant.)

"The factory was similarly treated. The effect of the working clauses in the last New Patent Act has been infinitesimally small from the point of view of bringing about new manufacture in this country, and the employment of labor. In no case has the Act resulted in any manufacture in the coal-tar dye industry continuing in this country after the patent has lapsed; for instance, while —_. was patented over here it was made in large quantities, yet the last English-made-was sold two or three months before the patent lapsed, and so it has been with everything else. It is impossible to produce any permanent results by these working clauses. Again, a number of patents have been revoked under the new Act. In no case has this resulted in the manufactures being effected in England. The inventor has lost his patent but there has been no manufacture resulting over here........

"I have now heard from London where I spent a few hours the day before yesterday, with reference to the compulsory working clauses. The Controller at the Patent Office assures the that there has been no official publication at all with reference to the effect of compulsory working.........

"The - Chemical Works bought 24 acres of land at 
$£_{I, 000}$ the acre, but they did this with the absolute conviction that five acres would be amply sufficient for a factory merely to work the patents. Indeed, with five acres the coefficient of safety was three.

"The factory of the Company at - C is similarly very much larger than is necessary for working the patents. The site covers, I believe, 25 acres. I am not sure of the exact size of the site. They use, I should estimate, three acres."

According to the Journal of Commerce of November 4, I9r4, the Farbwerke Hoechst plant in Ingland employed fifty or sixty workmen at that time; statements have been made by supporters of this clause that these works employed 600 workmen.

On April I, I9I4, the Imperial Industries Club of Great Britain had a real in-the-family and heart-to-heart discussion of this Act and its effects. The complete report of that discussion is given below with acknowledgments to The Imperial Industries Club, whose official pamphlet has provided this material.

Since this Act was passed for the benefit of Great Britain's chemical industry and particularly with the hope and expectation of creating in Great Britain a real coal-tar dye industry and has failed of its object, a careful study of this discussion at this time must appeal to every American chemist and maker of chemicals.

90 WILIIAM STREET, NEW YORK

\section{SYMPOSIUM ON COMPULSORY WORKING OF PATENTS AND DESIGNS IN ENGLAND ${ }^{1}$}

By The Imparial IndUStries Club

THE chatrman: My Lord Moulton and Gentlemen-We have received letters of regret from the following, who are not able to attend this evening: Sir John S. Randles, M.P.; the Hon. Sir John Astbury; Lord Parker; Ivan Levinstein, Esq.; C. T. Needham, Esq., M.P.; the Right Hon. Lord Southwark; F. Whitley Thompson, Esq.; G. J. Stanley, Esq., of the Board of Trade; Harry Nuttall, Esq., M.P.; A. J. Hobson, Esq.; Ex-Master Cutler, of Sheffield; and from Sir Joseph Lawrence, a member of this Club and an old friend of ours here, the following telegram has been received. Sir Joseph says: "I deeply regret cannot join you. If present I should stoutly maintain compulsory working benefits this country by creating more opportunities for employment and I strongly support this policy and would strengthen it by Parliamentary means. Please read this to your meeting."

Gentlemen, I think that that is a very good opening for the subject which we are about to discuiss and which I think you will all agree will prove a very interesting one. We are a comparatively small party this evening; but I think we are all in-

1 Report of the proceedings at the April dinner of the Club held at DeKeyser's Royal Hotel, Victoria Embankment, E. C., London, on Apri 1, 1914, with the President, Ald. Sir George Wyatt Truscott, Bart., J. P., in the chair. Among those present were the following: The Right Hon. Lord Moulton of Bank; W. Temple Franks, Esq., C. B.; Sir George Croydon Marks, M.P.; Sir R. Ellis Cunliffe, M.A.; Col. Sir John E. Bingham, Bart., V.D., J.P.; Sir Roper Parkington, D.I., J.P.; A. J. Walter, Esq., K.C. James Hunter Gray, Esq.; H. A. Colefax, Esq., K.C.; G. Henry Wright Esq.; C. E, Town, Esq.; Stanley Machin, Esq.; H. Hatfield, Esq., I.S.O.; Wm. Martin, Esq., IL.D.; Alex. Siemens, Esq.; Oliver Imray, Esq.; Alfred O. Goodrich, Esq.; Dr. Ernest J. Schuster; George Barker, Esq.; C. Freeman Murray, Esq.; The Hon. Hugh Fletcher Moulton; Laurence Rostron, Esq. C. Urquhart Fisher, Esq., I.C.C.; J. King Stewart, Esq.; John Cutler, Esq., K.C.; J. M. Forbes, Esq.; Achille Bazire, Esq.; R. B. Dunwoody, Esq.; Louis Sinclair, Esq.; Francis E. Truscott, Esc.; James Webster, Esq. W. Holmes Reddan, Esq.; R. A. Wallis, Esq.; Percy Richardson, Esq. W. A. Vernon, Esq.; Dr. A. E. Rose; J. K. Foord, Esq.; C.. Beatty, Esq.; Kenelm H. H. Smith, Esq.; Walter F. Reid, Esq., F.I.C., F.C.S.; Douglas Leechman, Esq.; E. T. Ayerst Hooker, Esq.; E. E. Pakeman, Esq.; Geo E. Pearson, Esq., F.C.S.; G. M. Whiley, Esq.; J. D. Marshall, Esq.; Ernest J. Mitchell, Esq.; Edward Harrison, Esq.; A. J. Martin, Esq.; M. P. Shepherd, Esq., A.C.A.; Henry Cooke, Esq.; J. H. Evans-Jackson, Esq.; J. N. Evans-Jackson, Esq.; Wm. J. Tennant, Esq., M.I.M.E.; H. Wade, Esq. Jacob Heilborn, Esq.; Geo. Kettle, Esq.; P. Blair Tayler, Esq.; Percy Izod Esq.; E. H. Harberd, Esq.; J. H. Jack, Esq.; and J. E. Evans-Jackson, Esq. (Hon. Secretary). terested more or less in the subject which we are going to debate. We are fortunate in having around this table gentlemen who are professionally, officially, and commercially interested in patent questions, and we are to have an opportunity of hearing, I hope, expressions of opinion which will voice both sides of the question. Because at this Club we do not like things to be altogether one-sided. Our purpose in meeting here is to try to thresh out matters in a friendly and convivial sort of way, and therefore we rejoice when the opener has some little opposition, so that those of us who do not take part in the debate are able perhaps to act as a jury of decision.

I am privileged to call upon Mr. Walter Reid, Chairman of the Institute of Inventors, to be good enough to open the discussion.

MR. WALTER F. REID, F.I.C., F.C.S.: My Lord Moulton, Mr. President, and Gentlemen-The reason I have been called upon to open this discussion has been stated by the Chairman, namely, because I happen to hold the office of Chairman of the Institute of Inventors; but I should wish for your sakes that you had somebody who is better able to place the arguments on behalf of inventors before you than I can do myself. I am very glad indeed to have the assistance of my old friend Sir Joseph Lawrence, because I was with him on the deputation to Mr. Lloyd George which resulted in the Patents Act that is now the subject of discussion, and that some of us, at any rate, wish to alter. Previous to that I had also taken part in a deputation to $\mathrm{Mr}$. Gerald Balfour, when he was at the Board of Trade, when we also got an alteration of the Patents Act. I do not know whether anybody was satisfied with that alteration, but I have not heard of many, and that Act was very soon altered. I think, when we are on that subject, it is not quite right to say that Mr. Lloyd George on that occasion gave one of the first and most conspicuous instances of Protection to British industry. He really did nothing of the kind; he placed us on a Free Trade basis with other nations, because undoubtedly - I will not go into the figures on this question-at that time the bulk of the other nations, the most important ones, who were competing with us industrially and commercially, had compulsory working as one of the conditions of granting a patent in their countries. We for a very long time had no compulsory working: we had allowed foreign inventors here to acquire monopolies in certain branches of industry, and they had made use of those monopolies in a way which those who were acquainted with the details of the subject could no longer permit Great Britain to labor under the disadvantage of. On the occasion when we had the last deputation to $\mathrm{Mr}$. Lloyd George a number of cases and details were given of industries that had suffered in Great Britain because foreigners had been granted monopolies here and had not worked the patents in this country, but, having the monopoly, they could demand from our own people prices which they at home could not obtain. A very familiar case was that of the alizarine industry, where our manufacturers here who had to use such dyes were paying about half-a-crown and the practical real value of the material was about sevenpence. Of course, our manufacturers were suffering there under a great disability as regards foreign competition because they required that dye; it was a dye which was necessary, and the wool dyers in Bradford and elsewhere had those excessive prices to pay whereas their German competitors had not.

Now, I think, if we consider that, it is a clear case where the British industry is handicapped and unfairly handicapped; and I would ask you to bear in mind that the first and original idea of a patent was a monopoly for the introduction of an industry into this country, and it was only at a later stage that the inventor was given a monopoly for the produce of his brains. Nobody will deny that an inventor ought to have something for inventing a thing; otherwise we should have no inventors in this country; they would go elsewhere. But I do think, myself, and, so far as I have been able to learn, and I think I am in as good a 
position as anybody to learn the opinions of inventors generally, they are under the impression that it is an unfair thing to British inventors that a foreign inventor should come here and acquire a monopoly and not do what the British inventor in most cases has to do from the very nature of the subject, namely, work the invention. I think that we, as an Imperial Industries Club, ought to see to it that the British inventor is not, at any rate, worse off than the foreign inventor. He cannot in many cases at any rate,-in some he can, but in many cases he cannotacquire foreign patents abroad in the same way that a foreigner can acquire a patent here, because there is compulsory working.

Now, no doubt some of those who will follow me may say that compulsory working is a mere matter of form and so on; but, if you have a powerful firm who insist upon that form and put the law in motion, then the British inventor who has a patent abroad may very likely lose that patent in some countries--not in all of them.

There are other points with regard to the working in this country that I think we as an Imperial Industries Club ought to consider. With regard, for instance, to munitions of war, on that deputation to Mr. Lloyd George we pointed out that at that particular time great industries were being founded by which the nitrogen of the atmosphere was being condensed, or con. centrated as it were, into the essential material for the manufacture of smokeless powder. I particulatly pointed that out. I said: Now there is an industry being created which, if it is not worked in this country, will leave us in time of war without the possibility of carrying on the work ourselves. An industry of that kind cannot be founded in a few weeks, and, consequently, unless the industries had been previously established in this country we should be in the position that if war broke out the saltpeter, which is an absolutely necessary ingredient for all explosives, would be contraband of war and we should not be able to obtain a supply, whereas our competitors, or our enemies perhaps, would be able to do so from the atmosphere. From establishing those industries they would be able to produce as much nitric acid as they required and we should be left without it. That, apparently, appealed to the Government at that time, and compulsory working was then established.

Now, it has not given us altogether what we want. I will not go into the legal argument. Mr. Justice Parker, whose name is a household word among inventors and well known in this room, has interpreted the law in a certain way. We had previously not interpreted it in that way. I do not propose to go into that, because my friend, Mr. Douglas Leechman, who is the Chairman of the Parliamentary Committee of our Institute, has inade a special study of that, and if you wish he will give you chapter and verse for everything in connection with the legal aspect of the question. But what I wish to impress upon the members of this Club is that the matter is to some extent an Imperial one. It is one in which we ought to consider those of our kith and kin more, I think, than foreigners who come here, and whom we welcome, by the by. I would not for a moment say that we do not welcome them, for a very large number of our industries in Great Britain have been introduced and developed by foreigners, and I should be the very last one to say that we should not welcome foreigners in every way, but I do say this, that we ought not to give them a monopoly which can in any way injure our own people.

Now, as a consequence of that Act during the time when, if I may use the word, it was active, several firms abroad came and established factories in this country and (without again going into minute details which would probably be rather tedious to you, but I have a very considerable number of figures on that question) a number of factories have undoubtedly been established and industries have been established under the pressure of the Act as we interpreted it. It is not enough to say that one firm or another has put up a factory in England, and they are not doing much, that they have done it just simply as a blind, and so on; that is not so much the question; those who are behind the scenes know very well that a number of patents have been introduced into this country under royalty to British firms that would not otherwise have been introduced. When an industry is introduced into this country, whatever it may be, there is eniployment for British capital, there is employment for British workmen and the industry becones established in this country and after the lapse of the patent the industry becomes an English one.

I would mention incidentally that the British Enpire now is to some extent, I will not say in the melting pot, but we are going through troublous times with regard to the British Empire. We have self-governing Colonies, and the bond that links our self-governing Colonies to us is one of gossamer, and we can only keep together by the most careful interchange of opinions and of commercial interests especially. When I say that we have seven of the High Commissioners or the Agents-General of our self-governing Dominions as Members of the Institute of Inventors, I think you will see that we deal with the matter from the Imperial point of view, and that is particularly the point of view I should like to impress upon you this evening. There are a great number of things that one might mention that really cause an Englishman to blush because we are so dependent upon foreigners for things which are absolutely necessary for our existence as a nation. Of course, we know very well the history of the Whitehead torpedo. Our own Government would not take it up and it had to go to Austria to be started and then our Government bought it at an inflated price afterwards. That is a very well-known instance. I myself have had an instance. I started the industry of smokeless powder. I could not get our people to look at it here because they said the sights of all the rifles in the Army would have to be altered. The French did not look at it from that point of view quite; they saw a little bit further and they started the industry. Then our people came in afterwards, a second, perhaps a good second; but the less we say about cordite when it was first made I think the better. I think it a shame for Englishmen that they do not and our Government does not push ourselves to the forefront of nations. They can do it and why should they not? Then, again, you may not know it, but the glass required for optical purposes in our Army and Navy is German glass. For instance, the periscopes of the submarines are made from German glass. If we happened to have a war with Germany they would not give us their glasses.

MR. J. E. EVANS-JACKSON: That glass is not the subject of a patent.

Mr. WALTER REID: Yes, I think so.

MR. J. E. EVANS-JACKSON: No, certainly not.

YR. WALTER REID: At any rate, any improvement upon it here would be to the advantage of this country. I happen to know something about that particular subject, because I am a member of a committee that studies this special subject; Sir William Crookes is also a member and we have very distinguished scientific men on it, and it struck us as being a great anomaly, and it struck me personally as being rather a shame that we should be dependent upon a foreign country for these things. If, as our genial Secretary says, there is tho patent now at the present time, I would point out to him that the glass that was developed by Schott of Jena was developed financially and in every way only through the assistance of the German Government. Whether they give a money subvention for carrying out these experiments or whether they grant a patent, the whole thing is a development of the industry of the country, and if any foreigner were to come over here and were to get a patent monopoly for a new kind of glass he could hold up the whole industry if he liked in time of war. As a matter of fact, we are dependent 
for that glass upon the Germans, and that is the point I wish to make here: the Germans developed that industry through the assistance of their Government. There are many other things where our existence as a nation, I will not say is dependent upon, but may be, at any rate, interfered with.

I am reminded that the time is getting short for my opening remarks. I have a number of other matters, but I should like to refer just briefly to the commercial aspect of the question. The patents that are worked in this country may be of very great value indeed. If there are foreign patents which are not revoked or worked in this country they may stand in the way. I happen to be a director of a company that holds a very large number of patents; I think they are put down at about $£_{140,000}$ in our balance sheet, and they are of considerable value from the point of view of master patents; they control a certain industry. If we had a foreigner come over here and get a patent that would stand in our way British capital would lose. It is a thing that affects commercial men even more than inventors.

Then, again, I would remark to you with regard to the working of a patent that it is extremely difficult-and this is a point with regard to which probably those who succeed me in speaking will say that the onus should lie upon the objector-to prove that a patentee does not work. That is a most difficult thing to prove. I know the legal gentlemen are in favor of that because that seems to be the general practice in the law, but it is not a practice without exception; there are many exceptions. I would point out here that it is almost impossible for a stranger to find out what is going on in any factory. We have an instance where a gentleman told us that he had tried for a year, he employed detectives and he found that the patent was worked; he found a tub in a kitchen; that was all he found and all he was able to find. If it is so difficult as to be almost impossible for an. Englishman to find out what his foreign competitors are doing in this country, then I think the purpose of the Act will altogether fail. If the, onus lies upon the objector to prove everything that the foreigner is doing I think it is quite impossible. With those few words I will conclude.

THE ChaIRMaN: I will ask Sir George Croydon Marks, M.P., to speak.

SIR GEORGE CROYDON MARKS, M.P.: Mr. Chairman, my Lord, and Gentlemen-I am very glad that our friend has wound up with a suggestion which I think gives the key to a great deal of the criticism which has come from that table. He speaks about being concerned with a company that has £ 140,000 written as the asset connected with patents, and he touches upon the financial side rather more strongly, I think, than he touches upon what I would call the commercial side. I, unfortunately, have had to deal with inventors and with manufacturers and engineers and others for a great many years, and I have not found that there is a disinclination upon anyone's part to improve their position or to improve their works, given a favorable opportunity. I have found, however, that in this country there is a lack of initiative, and a great deal of caution that one does not find in other countries. That goes a very long way to explain why some people succeed elsewhere, and others fail here. There are businesses in existence in this country which have failed, not because of foreign competition, and not because of foreign patents, but because the sons connected with the business that they found made for them by their fathers have not that initiative, have not that personal touch, and have not that knowledge that their fathers had to make the business. Hence it comes about that we find young men, who succeed to good commercial businesses, doing all that they can to show the people in the district in which they live that they belong to a different class from those poor manufacturers and the others; and if, perchance, they do happen to go to a works they just pass through it and pretend to have but a little acquaintance with the details; and is it any wonder that by and by the old-established firm finds it necessary to convert itself into a limited liability company in order that its declining trade may be bolstered up by capital caught from credulous people knowing nothing about the real decline; and then, when that business has failed, you have some of these prophets of woe coming along and suggesting: "We have lost our business owing to the wretched foreigners sending things here or patenting things here that we are not allowed to make"? I am perfectly certain that I could, within twenty minutes, satisfy any gentleman tomorrow morning that if you have some very good article here and you submit it to a number of old-fashioned firms, making them offers of it, they will turn that down straight away, and say they have no need for it; they have all the skill that they want in connection with their own firm; and if they cannot produce what is wanted then that which we offer them is no good at all.

Our friend spoke just now about the terrible things that are going to happen if, perchance, some patent connected with munitions of war happens to be held by a foreigner when war breaks out. Well, if we have to make up our minds that we have to depend upon that which we can do in these Isles, only upon that which we ourselves can construct and bring about, we have to look to something a little bit broader than patents: we have to look to food; because the same suggestion about starving a nation out could be quite as readily made as killing our industries by working us out. I know from my own personal knowledge a firm in America who have supplied the British Admiralty and the British War Office with things used on the British guns; and I have seen cheques today to the extent of over $£_{1,200}$ in connection with these things used during the last six months on British guns supplied from America, and there is not a single British firm connected with munitions of war that will take the patent up or be bothered about it when they have been approached. I could show our friends tomorrow letters from large firms whose attention has been called to these particular things; they mark it "secret" when they examine it, and then they send and tell you they do not need it. Why? It would be a reflection upon some member of their staff if they recognized that a person outside of that staff could do anything better than is there being done, and therefore it is refused. No, Gentlemen, your have to get a little nearer if you want to find the reason for some of the decline of our industries. You have to get a pride in industry as much as a pride in position: you have to make people as satisfied to be concerned ịn a manufacturing industry as they are to be concerned, say, with the profession of law or with the profession of medicine: they have to be as zealous in their work, and as eager to develop there as their fathers were if they are to hold the trade. The trades that exist today that were formed by good men years ago are only continued today very often by new blood having been brought in, owing to the sons having shown a disinclination to carry on the business; they take their money and clear out. I could give one illustration from Birmingham: the firm, who were fathers of the whole industry of the civilized world in connection with mechanical power, was that of Boulton and Watt, and yet their works in Birmingham were subsequently acquired and became works, not for the great engineering industry, but for the manufacture of scales, and so are used today; while the works on the adjoining piece of ground, employing about 3,000 men, was formed within the last forty years into the great world-wide engineering business of Tangye's, Limited, by four men, two of whom are still alive today. Those men formed an industry and developed it, not solely by their patents, but by their zeal and by their personal industry. The other firm, that had the world at its feet, let the thing go, because those who were to succeed them had not that personal pride and initiative in that which they were doing.

Patents cannot be put upon the same footing as ordinary 
articles. A patent is a monopoly, and to talk about free trade in patents is to put one opposite against another. The real remedy for the trouble in connection with the abuse of patents is that, if a patentee does not work it in this country after, say, four or five years, it should be automatically open to people in the trade, who desire to work it, to go to the Patent Office and require a license to be given on reasonable terms-in order that they should work that patent; and then by so working it they would develop and bring from abroad that skill which would enable them to improve that which was originally initiated from abroad.

When the Patent Act of I907 was being discussed in Parliament I fought it every line in connection with the compulsory working proposals. I pointed out then that the people who were clamoring for it did not know what they were clamoring forand by and by they would be sadly disappointed, as they have been. I pointed out that they were 11ot aware of the difficulties that inventors had to get their inventions adopted-and I was considered to be a man who was only professionally interested in these things; but, unfortunately, since then inventors and others have found out that this wonderful Act, which was going to bring about such a large amount of extra work for them, has disappointed them, and it has not only disappointed them, but it has disappointed the public to some extent. That Act of 5907 had marvelously good points in connection with it quite outside the compulsory working and quite outside those things connected with that part of the subject that we are now discussing, but those points have been largely overlooked. It was a new charter which was given to the same people who clamored a few years ago under the idea that if they stamped every article when it came into this country with the name of the country from which it came then that would make people demand English things, if they happened to see "Germany" marked on it or "Belgium" marked on it. Those people were then known by some of us to be deluded people and working for a "Will o' the wisp." They got the "Will o' the wisp," and, they did not burn their fingers or get any light, but after they had apparently got it they looked for it, and found it was not there; but what was there all the time was a departing trade that the foreigners had captured owing to the immense advertisement that we had given them by requiring that stamp upon the goods "Made in Germany;" thus making people, when they wanted a cheap article, say: We must go to Germany for it; England cannot possibly do it.

No, Gentlemen, we made a big mistake when we introduced into that Act of 1907 the compulsory working--a very big mistake, as the whole industry now recognizes. The "Inventors' Institute," I am glad to find, recognizes it; I am very glad to find that the commercial people recognize it and I would ask them now to direct their attention to getting a reform, not in the matter of compulsory working, but of automatic licenses, so that if a man does not work it, you can go and demand that you may work it. And if you demand that you shall work it he will then be obliged to come forward to prove that he is already properly commercially working it. That will be a very easy way of getting what our friends there desire, the proof that it is being actually worked, and the opportunity to work it, if the other man is not doing it.

Gentlemen, I have run past my time; but I am very glad to have had the opportunity of speaking. As one who was concerned with that 1907 Patent Act, who was on the conmittee when it was being discussed, who was present when Mr. Lloyd George received the deputation to which our friend referred, I am glad to be able to point out that that which was then originally declared by me as being something which would be bound ultimately to bring disappointment, has brought disappointment; and tonight here we must remedy it by going on a new path altogether.
THE CHALRMAN: I am now allowed to call upon Mr. Alexander Siemens to speak to you.

Mr. ALEXANDER STEMENS: Mr. President and GenilemenWhat I think about the working of patents $I$ said in a lecture before the Society of Arts some time ago, when I had this honor, that Lord Alverstone was in the Chair and Lord Moulton criticized. I will say at once that both those gentlemen sat upon me and flattened me out. They said I was absolutely wrong. Now I want, all the same, to repeat what I said then. First, I wish to back up Mr. Walter Reid in his statement that the Act of Monopolies originally made an exception in favor of those people who introduced a new industry into England; and I want to protest against giving the dog a bad name and calling it compulsory working. It is not compulsory working. Now, to make my reasoning clear, who is an inventor and what is inventing? According to my notion a man who wishes to improve processes which are in use ought to have a perfect knowledge of the natural laws referring to the subject. He ought to know what has been done before, and especially he ought to know the endeavors to improve some methods which have failed, because you learn more through failures than through successes. I will put everything very shortly, but you know petfectly well what I mean. And he ought also to know what is the demand; in what direction ought improvements to be made.

Now, what I contend is that the inventor, so-called, who is represented in the novels and children's books as going to bed one evening - quite sober, of course-having a lucid idea during the night and getting up the next morning a saviour of society, or a benefactor of his fatherland, and all that sort of thing, does not exist. As I have said already, the people who really can propose improvements which are worth having are those who have to do with the things all the time, who know what they are about and-I am coming presently to a point which displeased Lord Moulton very much-I think it is the manufacturers themselves who know best where the improvements ought to come in, and how to make experiments and conduct their researches in order to effect their purpose. The outsiders have no idea. It is, of course, always a story that medical men were the greatest electricians; look at Volta and Helmholtz, and goodness knows how many more; but if you come to look into it, take the medical profession, they devoted themselves entirely to electricity (I am just taking that example), and, of course, they were capable of suggesting the proper improvements. Now, the outsiders come with all sorts of rubbishy inventions, and it is almost impossible to convince some of them. In that respect, I would only retail to you a saying of Sir William Siemens. He used to say: "I have an appointment with an inventor this afternoon; that means I shall waste two hours of my valuable time, and I shall make an enemy for life" because no inventor ever believes that he is wrong. On the other hand, I want to go a little further about this compulsory working, or putting the thing into practical use. I want to protect the inventor in this way, that if he has introduced his invention so that it is used on a commercial scale, then it shall not be possible to upset the patent by anything but proving that the same thing had been commercially done before and that is really the point. I am sure you are all well acquainted with patents which ate fishing patents, which put something, for instance, about wireless. Wirclcss is in the air: somebody puts down a sort of provisional specification with all sorts of notions, and then he looks afterwards into complete specifications which are dated perhaps later than his own provisional, and when he files his final specification he embodies all sorts of things which he has picked up in the meantime. That such a man should be protected is wrong, and it is really only the practical introduction of an idea (an expression which $I$ prefer to use to compulsory working) which should protect it. If you like to suggest any topic to me whatever, I will suggest at once a patentable idea to improve it, but whether it will work 
is another matter, and that is the essential matter. If a novel idea really shows by practical introduction that it is worth having, then it deserves protection, but the mere stating of a novel idea is no good whatever. In support of that statement I would ask you: Do you know many inventions which are worked in accordance with their specifications? I think those of you who are practical people will know that there is hardly any invention which is worked as stated in the final specification. There are always practical modifications, modifieations of detail as they call it, but it is the details which are the essential things, and which prove whether the thing is practicable or not, and therefore the working of an idea is the essential thing, and not merely stating something which is beautiful to look at.

THE CHAMRAN: We are now to have the pleasure of hearing Mr. Oliver Imray, ex-President of the Chartered Institute of Patent Agents.

MR. OLIVER IMRAY: Mr. Chairman, my Lord, and Gentlemen -A good many of my views have already been expressed by Sir George Croydon Marks. I fully endorse everything that he says.

Gentlemen, what we have to consider is: What is a patent? A patent is a monopoly; and without the grant of a monopoly. of some kind you cannot expect any capitalist, any manufacturer, to introduce a new invention into this country. He must have some sort of protection so that if he puts capital into a patent he is going to have the monopoly for a certain period. Now, Gentlemen, the monopoly granted to a patentee is absolutely absurd as compared with that granted to the author of a book. Further, Gentlemen, a patent can be attacked, first of all on disconformity between the provisional specification and complete specification, on novelty, either prior publication or prior user, on the question of subject matter, on the question as to whether the specification properly describes the invention-there are four or five grounds on which a patent can be attacked. Compulsory working introduces a further ground upon which to attack that patent.

Now, Gentlemen, if you come to think of it, there are 100,000 patents in force, in existence, at any time you like to mention. I have taken out the statistics. I know it for a fact. There are I00,000 patents. What has been the result of the 1907 Act? To take an average, there have been five patents a year revoked on the ground of non-working. For the sake of those five patents a year, you introduce an additional clause for revocation of a patent, or for attacking the validity of it. Is it worth while doing that? I say it is distinctly not. Gentlemen, are inventors to be encouraged? They not only produce an income of over $f_{100,000}$ a year to the Revenue, but they supply employment for the Patent Office and its officials to the amount of $f_{150}$,000 a year. Surely you ought to consider an inventor, and do the best you can for him! I have had thirty-five or forty years' experience of, not only the working clauses of this country, but the working clauses all over the world, and I say the compulsory working is a great farce, absolutely. You can always get outside of it.

Now, Gentlemen, I agree that compulsory working to the general public is an absolutely ideal measure. It is supposed to introduce inventions into this country, and to encourage the employment of labor. That is true enough, but the result of compulsory working from my experience, and from the first few actions brought for revocation, was not to introduce the industry into this country, but to revoke the patent, and allow Germans and Belgians, and French people, to dump their goods in this country.

Gentlemen, I hope, if any other legislation takes place, it shall not make the compulsory working clause more drastic, but shall amend it in this sense: that before a person can apply for revocation of a patent on the ground of non-working he should in the first instance say that he has applied for a license, and it has been refused-that is a very good ground; and not only that, but that he is prepared to actually manufacture in this country if the patent be revoked.

THE CHAIRMAN: I will now call upon Mr. A. J. Walter, K.C.

Mr. A. J. WALter, K.C.: Mr. Chairman, my Lord Moulton, and Gentlemen-The motion which I apprehend we are gathered here tonight to discuss is the proposal made by the Manchester Chamber of Commerce to the effect that the Association urges upon His Majesty's Government to amend the Rules under the Act of 1907 in such terms as will place the burden of proof of working in this country upon the patentee. A more mischievous resolution $I$ have never had the opportunity of seeing.

What is the meaning of a patent? It is that reward which every State has found it necessary to institute in order to encourage invention. Various countries, Belgium and Switzerland among others, decided that they would have no monopolies. They found that invention dropped off at once, because there was no incentive to inventors to employ their inventive faculty. Compulsory working is dictated by nothing else than the desire of others to destroy the monopoly which the State has given to the man who has made the invention and to enjoy the fruits of that invention. Compulsory working has been suggested purely and simply by the desire to appropriate the brains of others, by persons who have not the intelligence to invent themselves. It is the destruction of the very right which the State has given to the man as a reward for his having exercized inventive faculties.

I have had, perhaps, more experience than anyone in this room of the class of persons who present petitions for the revocation of Letters P.atent. I have known no case where petitions have been presented by persons who desired to work the invention in this country. Petitions are always presented by persons who have in some instances initiated manufacture abroad in order to come and present a petition to the Courts of this country so that they may say that there is a greater working abroad than there is in this country, in order, as has been graphically and euphemistically described by an earlier speaker, that they may dump their goods in this country; and I know of no bona fide petition presented by any person in this realm for the revocation of Letters Patent for the purpose of encouraging manufacture in this country; but, on the other hand, all petitions have been presented for the purpose of encouraging manufacture abioad, and destroying manufacture in this country.

I am, to a certain extent, with the motion in the sense that a patent is essentially a territorial monopoly presented by the Government of a country to an inventor who has benefited the country by making an invention for which they have granted him the patent, and who, if he is a bona fide inventor in the realm, will work that invention without any legislation of any kind or description. My experience is that if a man has an invention that is worth working there are very few commercial people who in time will not ascertain its value and assist him in working it without any legislation of any kind. If it is not worked it is for one of two reasons: either that it is valueless, and therefore had better be left alone, or else that the patent has been obtained by a person not domiciled in this country for the purpose of preventing working in this country, and manufacturing abroad, and importing into this country. I should draw a broad distinction myself in the case of inventors of other countries who take out patents in this country, not to benefit this country, but in order to dump their goods here, and prevent anybody manufacturing in this country. That is one class of harmful monopoly at which undoubtedly legislation might properiy be aimed. I would apply that equally to English inventors in foreign countries. If any inventor takes out protection in countries other than his own in order to stop people in those countries working in- 
ventions, I would devise measures to see, as Sir George Marks said, that he shall be compelled to grant licenses; but in the case of the inventor in this country who is working in this country, and who has not taken out patents in other countries, or, even if he has taken out patents, is not able to work them there, I would not allow him-as the law at present is-to be liable to have set up against his volume of trade in England the volume of trade in the patented article all over the world, over which manufacture he has no control whatever, and probably knows nothing about-to be put in the pillory to answer questions as to whether or not the manufacture in this country is greater than the manufacture abroad. That is the law in this country on the interpretation of the Act of 1907 , a position which I venture to think no sane person can ever have contemplated in Parliament, though the words of it undoubtedly do imply so. Lord Parker held, under the terms of the Act of 1907, that a patentee in this country, having only a patent in this country, could have a petition presented against him for revocation of the Letters Patent if the manufacture abroad, which he neither controlled nor had anything to do with, was greater than the manufacture in this country. I say that to put a patentee in such a position is absolutely unjust. (MR. J. E. EYANS-JACKson: "Monstrous.")

I have no objection, personally, to a system which would compel a person who takes out any territorial monopoly, the territory being that in which he is not domiciled, to grant licenses, as Sir George Marks says. Supposing a German takes out a patent in his own country and in this country, and does not work the patent in this country at all, but uses England as a dumping ground I should compel him to grant licenses. Similarly, I would compel an Englishman who works in this country, and takes out a patent in Germany, and does not work there, but dumps his goods into Germany, to grant licenses in Germany.

What is the present position of compulsory licenses? It has been my privilege, I think, to be in every compulsory license case which has come before the Courts since the Act of 1888 , and what has been my experience with regard to those? There has been no bona fide petition presented. It has always been the desire of the "Have-nots" to share in the benefits of the "Haves." Take the great monopolies of recent years: the Dunlop and the Welsbach, where there were huge industries introduced by reason of the patent monopoly granted. In every case the petitions presented against those companies were by persons who made fictitious improvements, not of any value whatever, and who then applied for licenses to work the monopolies of the Dunlop Company and the Welsbach Company. Is that the sort of way in which inventors are encouraged by a country to exercise invention? The conditions under which compulsory licenses are granted should be entircly altered from those which exist at present; and all those persons whom I call the "Have-nots," who desire to share in the blessings of the "Haves," should be by rules prevented from troubling patentees with their desire to reap where they have not sown.

Personally, I object to the whole of this grandmotherly legislation. It is grandmotherly. Commerce will look after itself, and if inventions are worth anything they will be worked, and the industrial members of the community will look after them. It is no good quoting as Mr. Alexander Siemens did, a remark of his great ancestor: "that most inventors wasted a couple of hours of his time." It is quite true that there are so-called inventors of that type; but a man of the ability of anyone of the name of Siemens would in five minutes recognize whether he was dealing with a crank or whether he was dealing with a man who had goods to sell, and if he found that he had got goods to sell, and they were goods in which he dealt, he would very readily make a bargain and deal in them. On the whole, therefore, though, as I say, I do not oppose anything which would prevent patents being used by citizens of other countries to stop working in this country and to assist the dumping of their goods in our country, I think that the whole legislation, both with regard to compulsory licenses and with regard to compulsory working, is a hindrance to trade, and a hindrance to invention, and should be abolished in toto.

THE CHAIRMAN: I will now call upon Mr. Douglas Leechman.

Mr. DOUGLAS IEECHMAN: MP. President, my Lord, and Gentlemen-So much has been. already said that I wanted to say that I shall not trouble you very long. I take it that the object of this Club is to promote the industries of the country, and we will all admit industries are very largely founded upon inventions. Inventions, therefore, should be encouraged, and they should be encouraged in the form of granting Letters Patent, and the Letters Patent should be worked in this country as much as possible. I think everybody wants to see inventions carried into practice and not merely left on paper. Further than that, the patent when granted should be maintained if possible. In that connection I should like to say right away that you are not going to encourage trade or invention or patentees by saying, "Either work your patent or lose it." If you are going to get the benefit out of the inventions that are made by the patentees you must preserve the patents and not hold. a pistol at a man's head and say, "Work it or die," because nobody wants, or I will not say nobody, but in very few cases do manufacturers care to take up an invention for which they will have no protection. If a man is to take up a new thing he wants to have some privilege in connection with it.

Now, I should like just to echo Mr. Imray's reference to the extracting of $£ I 00,000$ a year from poor inventors by the Patent Office. I do think that the Government are not quite doing their duty to inventors in that connection. If they want to encourage the poor inventor, as the present Patent Act is supposed to do, they ought not to say, "You shall pay gd. for $4 \mathrm{~d} . "$

Mr. A. J. Walter, K.C., has so amply dealt with the result of these petitions for revocation that I need not dwell upon that subject; but these petitions do not go to promote industry in this country; they throw the invention open to everybody if the petition is granted; and, as I have already said, that does not promote our trade.

Now, the working of inventions should be promoted, and to that extent I am in favor of compulsory working, but not in the form of threatening a man with revocation. If you want to insist upon an invention being worked you should make the inventor grant a license, if he will not work it, or cannot work it himself. The patentee is not a dog in the manger. There may be a very few patentees who are dogs in the manger, but theirs is not a typical case. If I may echo what Sir George Croydon Marks has said, the dog in the manger is the manufacturer. He says, "I do not believe that you have anything better than I have got, but even if you have, I an not going to look at it." He feels that his sense of dignity is lowered if he takes up an outside invention.

What I would advocate would be the simplification of the grant of compulsory licenses. At present we have this extraordinary position. The Comptroller-General will forgive me for likening him to a magistrate. At present the position is that the magistrate may pass the death sentence in the form of revocation; but if you want to commit a man for six months, or whatever the period of the license is, you have to go to a Judge of the High Court. I would like to make compulsory licenses as easily obtained as compulsory working is at the present time. One should file an application with the Comptroller, and he should be able to deal with it. The reason why compulsory licenses have not been popular in the past has probably been because of the difficulty of working the machinery. I should like to see Sections 24 and 27 , those relating to compulsory licenses 
and compulsory working, amalgamated. One should give the control of the matter to the Comptroller-General, and revocation might come in as a possible alternative. That is to say, if a man refused to grant a license on reasonable terms, then he should be told, "Very well, then you shall lose your patent altogether."

Finally, I should like to say how thoroughly I disapprove of the idea of throwing the onus of proving the "main" and "extensive" and "adequate" and "satisfactory" working in this country. upon the patentee, upon the mere allegation of the applicant for revocation to the contrary. If an applicant has not got enough information to make out a prima facie case to support his application, then it is not worth much.

the chatrman: Mr. H. A. Colefax, K.C., will now kindly speak to us.

MR. H. A. COLEFAX, K.C.: Mr. Chairman, Lord Moulton, and Genilemen-I should like at the outset to express my appreciation of the kindness you have done me in inviting me here this evening. When I received the invitation I was acquainted at the same time with the fact that it was proposed that this question of Compulsory Working should be discussed here tonight. I confess I was a little surprised; because it seemed to me rather as if to discuss that question was an unwarranted interference with what I had regarded as the certain but slow death of an unsatisfactory statutory enactment. However, I discover that in that conclusion I was wrong, because I did not know at the time what I know now, that the Manchester Chamber of Commerce is apparently still on the war path. We know that in large measure the Manchester Chamber of Commerce was responsible for this provision in our statute law that we are discussing tonight. See what it is that they are proposing now. They have got their enactment, and surely, from the standpoint of cheapness and ease with which anyone can come forward and claim on this ground that a patent should be revoked, the provisions in force I should have thought left nothing to be desired; but, apparently, they do not satisfy the Manchester Chamber of Commerce, and they are asking now that there should be an alteration in the rules; and that alteration, I think, we can put quite shortly in this way. They are proposing that when the plaintiff has put forward his case, not proved it, but merely alleged it, then the defendant, the patentee, should be called upon to disprove that case. Well, I venture to think that that is really an unheard-of proposition and would be a gross injustice to patentees in this country and more particularly when one thinks for a moment what is the position under these provisions, We have heard a great deal lately of the common informer, and I cannot help thinking that these provisions which are in force today do really put into the hands of a man, who need be nothing more than a common informer, a right to come to the Patent Office and demand the revocation of the patent. Now, I think it was Mr. Reid at the outset of our proceedings tonight who suggested that these provisions had as their object to give more employment in this country. I do not think that is correct. I remember one of the very earliest cases, and I have been engaged in a good many of them, and I dare mention this case, because although the Comptroller is present, it was not his decision, but the decision of his predecessor. It was a case of this character. There was a patent here for a certain invention, and by an oversight no patent had been applied for in Germany. There was no question that the patent could have been obtained, but by an oversight it had not been applied for. The applicant for the revocation of that patent was a foreigner, who did, I believe, a commission business in the City of London; and his object in applying for revocation was not in any way to give employment in this country except to himself. But what he did seek to do by revoking the British patent was that he might be able to import a German-made machine into this country and so sell it freely. That is one of the very first cases that I remember under this Act.

Something has been said also, I think it was by Mr. Reid, about Imperial unity. I confess that that is a subject that I feel strongly about myself and in every way desire to further. But it does not seem to me that these provisions in any way make for that, because, unless I am mistaken, our Colonies have copied our Act in so far as they have altered their legislation since the I907 Act has been passed, and in several instances have incorporated into their Statute law provisions exactly similar to those which we have in force in this country; and therefore so far as Imperial unity is concerned it seems to me that it rather makes away from than in favor of that valuable objective.

Now, upon this question I, personally, have not a shadow of doubt. I have had a good deal of experience, and I am absolutely convinced that at present there is no countervailing advantage obtained under these provisions. The path of an inventor is beset with very considerable difficulties and every one of us who has to work in connection with patents, and deal with this question, knows the enormous pitfalls there are in the way of a man who has made an invention obtaining with certainty valid protection for that invention and I venture to think that he ought not to be saddled with these provisions unless it is absolutely clear that there are paramount countervailing advantages, and of those at present I know of tho evidence.

One aspect of this question has not been alluded to tonight, and I should like just to mention it, because you will remember that under the Act it is not only possible to apply to the Patent Office for revocation, or by petition to apply to the Courts for revocation, but it is also possible for a defendant to raise by way of defense a plea that the invention the subject of the patent has not been worked in this country. I do not know how many times that defense has been raised, but it is within my own knowledge that it has been raised a great many times. One case I remember in which it was raised-I could cite more than one, but one occurs to me just now, namely, the Vidal Dyes Syndicate vs. Levinstein. It is germane to what we are disctussing tonight. What happened there is what I think has happened in every case. The defendant was raising among other defenses, that the invention would not give any useful result at all. Well, he very soon found himself in this curious. position, that in urging that it had not been worked to an adequate extent in this country as compared with abroad, he was relying upon a defense which conflicted with the plea that the invention could not lead to any useful result. There are many. other cases; but I believe that in no single case up to now has that defense ever been presented to a Judge for his consideration or his judgment. So far as the application to the Patent Office is concerned, I, personally, join with what has been said by more than one speaker tonight, and that is this, that this procedure is not a wise one, and if in truth what you want to do is to make it so that a man who is enjoying the monopoly of an invention should either himself put in operation in this country his invention, or that otherwise it should be put into operation, then I feel myself most strongly that the proper and fair course is to alter, if not satisfactory at present, the procedure for compulsory licenses and that by a compulsory license you have the right way to attain that end.

Now, there are only one or two other matters I would just mention before I sit down. Something has been said by my learned friend, Mr. Walter here, about the decision of Lord Parker. I am not questioning its soundness from the standpoint of a legal decision, but I confess that if these provisions are to stand, and that decision is to stand, there is something very wrong in the application of the Act, because I cannot believe myself that it was ever intended that you should on the one hand look at the extent of manufacture abroad and contrast that with the extent of manufacture here, when all the time the 
poor unfortunate patentee here may have absolutely no control whatever over the manufacture abroad. Surely, if you are going in any way to endeavor to apply such provisions as these, they ought to be provisions applicable only under these conditions, that what is contrasted is the sale of the article, whether imported or otherwise, in this country, with the extent of manufacture abroad, and nothing beyond that. It is quite true that the patentee at the moment has an ofiset to that position as decided by Lord Parker, in that he may include among the working in this country the infringing working, which also has always seemed to me a somewhat curious decision. At any rate that is the position of affairs.

Well, Gentlemen, so much has been said upon this that I do not believe I can usefully add more; but I would join with those who take up the standpoint that if we are anxious to see that an invention enjoying a monopoly in this country should be worked here the proper course is by compulsory license, and not by these provisions as to compulsory working.

THE CHAIRMAN: Gentlemen, you will have noticed with very great pleasure, I know, the presence among us of the Right Honourable Lord Moulton. We are very grateful to His Lordship for coming here this evening, and I am grateful to him, and so will you be, that he has consented to address us.

THE RIGHT HON. LORD MOULTON OF BANK, P.C., F.R.S.: Mr. Chairman and Gentlemen-I have enjoyed these speeches very much, but there has been a tinge of regret. There was a time when I could have made just as fiery a speech as Mr. Walter and, in fact, there was a little in the swing of his sentences which made me think that perhaps I had not been wholly strange to his education in that matter. But you see I am a tennis player turned umpire, and $I$ have grown to look at strokes with a very much cooler head than I used to in those days when I played, and I have been trying, while this very interesting debate has gone on, to keep myself in the attitude of mind that one tries to keep one's self in when one hears a case: you hear the arguments on both sides and then you give your judgment. It does not follow that your judgment will not be strong. It is quite possible that the case may be so good, or so bad, that you not only use verbs and nouns, but you also use adjectives.

Well, Gentlemen, so far as the legislation as it stands, about compulsory working is concerned, I an afraid I am going to use adjectives. I think it is not only mischievous, it is also idiotic. It is one of those cases which are growing to be common, where the layman rushes into legislation with little or t1o acquaintance with the subject on which he is legislating. Knowledge has gone so far that the layman cannot keep up with the technical knowledge of a subject, even in politics. In my opinion, it would have been impossible for any man who understood this matter to devise the present legislation.

Now, let us take one example, and remember when you are testing whether a thing is right or wrong by an example, you must never take an extreme example; you must take one which fairly represents it. Let me suppose that a man makes an invention and contents himself by taking out an English patent. The invention turns out to be of world-wide utility; it is adopted, we will say, by every civilized nation in the world: but the inventor has no rights abroad: he has rights in England only. Then comes some person and says, "Your patent is worked mainly abroad." Of course it is. Big as England is, the world outside is bigger. Then he appeals to this legislation, and claims that the patent must be revoked because it is worked mainly abroad. In this he is justified and the consequence is that an invention that is universally valuable and universally appreciated stands in the eye of the legislation of Fingland, as it at present exists, as condemned to death, and it will be revoked unless the poor inventor can explain how it is that a useful thing is used more abroad than it is in England.
It is no use arguing about legislation of that kind. It is selfcondemned. We should be wasting our time here, if we discussed whether it should or should not be altered. Accordingly, I prefer to utilize the time in considering what is the real mischief that has driven people to such extravagant and ill-judged legislation. I do not hesitate to say that the very able Minister who fathered that Bill and got it through the House of Commons literally saw red when the word inventor was mentioned. $\mathrm{He}$ looked upon this poor harmless set of people as wolves ravening on the unhappy British public. And he apparently is not the only person who does so. I have heard here the representative of a great name quoting the authority of one of the greatest nembers of his family to the effect that whenever he met an inventor it meant two wasted hours and the making of an enemy. $\mathrm{He}$ is quite wrong. I could mention an inventor whom I very often saw, and sometimes was lucky enough to have two hours with. But I neither made an enemy nor wasted my time, for that inventor's name was Sir William Siemens.

MR. ALEXANDER SIEMENS: You are not a manufacturer.

LORD MOULTON: I have seen many inventors, and so many of them are people whose lives are almost eaten up by the idea that they are trying to nourish into usefulness and strength, and I think that if $I$ had one of them before me, and he did not know anything about the legislation as to patents, and I told him, "You know that now they have passed a law for the compulsory working of inventions," he would have said, "Oh, thank God, that is all I want" because he would firmly believe that his idea was such that if it was only worked he would prosper. Such compulsory working of inventions would be the greatest possible boon for an inventor, but the present law as to compulsory working is well-nigh fatal to the chances of remuneration which he would otherwise have. It punishes him for want of success which is not due to his fault. I challenge anyone of those here present, whatever view he takes of this subject, to answer me this question. Did you ever know an inventor (who was not also a manufacturer) who was not eager to have his invention worked everywhere? The mischief that has stirred up people to pass this legislation is that manufacturers, not inventors, stop the use of inventions in this country. Just think of the cases. Do you think that a man who invents a new dye would not like it to be made by Mr. Levinstein as well as everybody else. But it is a different question when a great foreign firm gets it. They do not want to protect the inventor's rights. They want to protect the manufacturer's rights. The consequence is that the whole cause of the outcry is the manufacturer who wants to get a monopoly by means of the rights which we have given to the inventor as a reward for his original thought, and you never find any mischief of the kind that it is supposed we must guard against as long as the patent remains in the inventor's hands. I smile when I hear those who take the opposite side in this controversy talk about the advantage of compulsory working because it brings trade into England and gives work to our working class. Mr. Levinstein is an old friend and an old client of mine, but do you think he conducts his campaign in otder to bring the Badische Anilin und Soda Fabrik into England? No, no, no. If you strip the cases of the formal language in which they are put, you will always find that the man who wants to revoke a patent is a manufacturer who wants to prevent the inventor proper from getting the return of his invention. I have said that I never knew any inventor, who kept the interest in his invention in his own hands, who was ever unwilling that it should be worked as largely as possible in every country in the world. Occasionally you may find a crank who puts too high a value on his invention, and will let the few years of the patent pass and his invention remain unused, simply because he thinks that the royalties offered are too low, but those cases are so rare that they may be neglected. No, the applications to revoke patents are not for the purpose of in- 
creasing the manufacture in England; they are for the purpose of increasing the importation into England. It is this which makes it so important to give to people clear ideas on the subject. As you know, it is quite possible that the specious appearance of a movement in favor of English manufacturers (and it can be clad in those words) may bring some attempt to increase the severity of the law. This can be resisted only by showing to the world, first of all, that the movement is always from the manufacturer-the inventor has no interest in limiting the use of his patent-and, secondly, that the aim of all these attempts is to increase importation into England, and not manufacture in England.

So much for the real substance of the case. What then is the true remedy? The true remedy is that you ought to protect the monopoly of every inventor who behaves reasonably and punish those only who act unreasonably. If an inventor sells his rights to a foreign manufacturer, and that foreign manufacturer uses the English patent to prevent manufacture in England, a manufacturer who is willing to make the article in England ought to be able to get a license to do it. No patent ought to be used for the purpose of checking work in the country itself. But let me point out the dangers that there are in taking a principle like that and using it without knowledge and without caution. There are many things that are best manufactured by one or two firms. The demand is small for them, and one or two firms can well satisfy it. If you threw it open to hundreds of firms you would get no greater benefit to the country. (A voice: "Less.") Therefore we have adopted the rule, and I think it is a wise one, that the inventor should be left to manage his own patent, fix his own royalties, and get as much from it as he can with his own personal knowledge of the matter. But if he acts so unreasonably that the patent is having the effect of seriously checking working in England, then give the power to the Courts to grant a compulsory license. That is remedy enough, and I should counsel you not to do anything else whatever. If you do you will find that all you are doing is to help people to take the ideas of the inventor without giving any fair return, and to help people who manufacture abroad to import their goods into this country without remunerating the inventor. We do not want to see that, because we desire to see English manufactures increase; for we feel that we have a growing working population. We are glad to welcome new industries to develop in our midst; but, if we try to bring that about by unjust laws, you may be perfectly certain you will do more harm than good, and ultimately you will regret it.

MR. ALEXANDER STEMENS: Mr. Chairman, may I say one word about what Lord Moulton said with reference to my remarks -about Sir William Siemens? Sir William Siemens was interviewed by an inventor, who wanted him to pay him money, but when Sir William Siemens interviewed Mr. Fletcher Moulton, as he was at that time, he was consulting a barrister.

THE CHAIRMAN: It is interesting that the next name on my list is that of the Hon. Hugh Fletcher Moulton, and I will ask him to address us.

THE HON. HUGH FLETCHER MOULTON: Mr. Chairman and Gentlemen-The Chairman's conduct explains something for which the reason at first was not obvious and that is why it was not he but somebody else who was called on to say grace. Obviously, this was on account of his lack of scriptural knowledge, for there are certain things which you learn in the Scriptures and one is: Do not first place your old wine before your guests and then the new, because truly they will say the old is better. I very strongly object to the order in which the members of my family have been called on.

.With regard to the subject of the debate I will say this: the whole of my natural instincts are in favor of compulsory working. On the other hand, the whole of my trade knowledge shows me how useless it is.
Now I have a great deal of sympathy with the principle of introducing working in England, but I do feel that with regard to the means for accomplishing this we shall find again that the old is better. The old idea of introducing a new manufacture was to give it a monopoly, to protect it from competition. I am a believer in Free Trade; I an a believer in the principle that it is a good thing to give a healthy baby a cold bath; but I am not a believer in the principle of exposing a baby, who has been judicially found to be in a weakly state, under Niagara, and it seems to me that, when you find a manufacture is being wholly or mainly practised abroad, to say that the best way of introducing it into England is to destroy the protection of monopoly, is an utter fallacy.

The gentleman who opened this debate has appealed to the Colonies. I also appeal to the Colonies, and I say we might very well follow them. Take the case of Australia. In the case of Australia they did not wholly reject the assistance of men who knew something about the Patent Law. There is a gentleman present here tonight who had a great deal to do with the drafting of the Australian clause. And what did they draft? They drafted a law which provided that in the case where a patent was not sufficiently worked there you. could get a compulsory license. That ought to be the principle here. That enables the manufacture to be introduced here under the protection of a monopoly. Even in an extreme case, if you wanted to say to the patentee that he is to forfeit his whole right, I should say that he ought to forfeit it to the Crown and that the Crown should keep the monopoly and grant licenses to British manufacturers rather than to say: This industry is established abroad and we are going to abolish all possibility of introducing it here under the protection of a monopoly.

There is one thing we have been discussing, viz., the proposals of the Manchester Chamber of Commerce, and nobody has ventured, perhaps in courtesy to the opener and to those who support him, to refer to the provisions of the Bill prepared by them. I propose to break through that convention. This new change is supposed to be in the interests of business men. I wonder how many people here have read the Bill which the Manchester Chamber of Commerce wish to introduce. (Mr. J. E. EVANS-JACKson: "Not one.") One of the proposals is, that if anyone has a patent, a common informer can come forward and say, "I believe this is being worked more abroad than it is in this country; I call upon the firm to produce the whole of its books and demonstrate to us that it is not"-a pleasant prospect for a really business firm. Here is another of the proposals: Any contract in reference to any patented article is to be filed with the Attorney-General for publication. I wonder how many business firms would have supported that provision if for one moment they had understood what it meant? I do not want to be severe on our friends here, but I do feel that we have a duty to the business community and one of those duties is to protect it from its so-called friends. Now, Gentlemen, time is nearly up, but there is one thing for which I am going to thank the opener from a purely personal point of view, and that is, for referring to the glass industry in Germany. Why I am glad he referred to it is because it refers to a project which is very near my own heart and because there are at least two members of the London County Council here. Anybody who knows anything about why the German glass industry is so prosperous knows that it is because of the munificent sums which have been spent in Jena in cultivating research in optical glass. For some ten years that same project has been before the County Council in London, and I ask our friend, Mr. Urquhart Fisher, to weigh those remarks and see that they are brought to a practical conclusion and to found that optical institute which has been promised for so many years.

I only ask our friend who opened the debate to consider whether the opinion of so many people who pass their lives in 
close touch with inventions ought not to be considered-whether it ought to be brushed aside as interested or whether he ought not to feel that there may be something in it and that perhaps the best interests of the inventors and the best interests of trade generally will not be served by those who "see red," but by those who think how best to introduce an industry to England without unduly penalizing inventors.

THE Chatrian: Mr. J. Hunter Gray will perhaps speak, MR. J. HUATER GRAY: Mr. Chaiman, Lord Moulton, and Gentlemen-The description Mr. Walter Reid gave us of his visit to the President of the Board of Trade reminded me of the gentleman who had a slight headache from time to time and who went to a specialist and asked him what was the best and absolutely safe cure. The specialist said, "If you get your head taken off you may be quite sure you will never have a headache again." I suggest that the section which is now under discussion was drafted on those principles.

For my sins I have had a very close association with the litigious aspect of this section from the time it became law, and I think I may say that without exception the applicant for revocation under this section was, so far as I remember, in every case a foreigner, and in no case had the applicant any intention whatever of manufacturing in this country. It is the greatest satisfaction to me to hear tonight that the master of the last two generations in the theory and practice of patent law agrees with the opinion, so far as I can gather, of the whole of this meeting, that this section can be detrimental only to invention in this country.

I want to tell you one experience, and I assure you it is not the only one (there are some here who can corroborate what I say) that I had not very long ago where an application was made under the following circumstances: A well-known motor firm was asked to give an advertisement to a particular paper, the circulation of which was stated to be 10,000 , but which circulation, on inquiry, was found to be a free circulation. Naturally enough, the motor firm did not think it desirable to give an advertisement at the price asked; whereupon this particular paper informed the firm that they would apply to revoke the patents, and the result was that there were some ten or twelve-I forget the number, someone here will correct me-applications, costing is. each, applying to revoke the corresponding number of patents. These applications were filed in due course. Under the then practice of the Patent Office it would have been the duty of this particular firm, who are carrying on a very large business in this country, and a very profitable business both for the public and for themselves, to disclose all their books, to say what their sales were and to say to whom they sold; but, fortunately, some of us were determined that we would find out what the particular applicants knew. It cost them, I think, I 4 S. to make the applications. I may tell you that the capital of the Company that made the applications was $2 \mathrm{~s}$. paid up. Upon that it was thought proper by those who advised the patentees to object to putting in any evidence disclosing their sales, where they made them, or where they got their patented articles. The result was that these applicants, on being asked to appear before the Comptroller of Patents, decided that rather than be cross-examined they would drop the applications. But, in the meantime there had appeared all over the country advertisements about the size of one wall of this room: "10,000 motorists involved; 20 patents to be revoked." And that was the sort of thing that was exhibited all over the country.

This Section of this Act of Parliament stands today as it did then; fortunately for the public, fortunately for inventors, the High Court and the Patent Office have thought fit to make it necessary that any person who applies to revoke a patent shotid put forward a prima facie case. But, nevertheless, difficulty remains as regards the High Court because there the procedure is entirely different from that of the Patent Office. I say that the Section is an un-English Section in an English Act of Parliament; because it introduces, for the first time, the principle that a person is guilty until he proves his innocence. In any other proceeding of any kind a person is presumed to be innocent until he is found guilty; but a patentee is a criminal; he is a person who is to be loathed; he is to be attacked and he is put on his trial; he has to prove that he is an innocent man before there has ever been any evidence that he is guilty. I submit to the industry-there are many members of the industry here that this section only requires to remain long enough to not only seriously affect invention in this country, but to min it. There can be no question that, although there may be thousands of perfectly useless inventions which are made by private inventors, there is the one in a thousand which is enormously valuable. One knows that the dificulties of inventors apart from this section are enormous at present, but when you have the added difficulties of compulsory working, an inventor having once been put to the trouble of having to spend $£_{5}, £_{10}, £_{15}, £_{20}$ or $£_{100}$ on an application to revoke his patent by a foreign firm who knows nothing whatever about him, will never invent again.

In my view the position is amply covered by the 24 th Section of the Act which says that anyone who wants to work a patent is entitled to apply for a compulsory license. I agree that in the past that provision in the previous Acts was a difficult one. It was provided under the jurisdiction of the Privy Council. One knew that was an expensive and a difficult proceeding. Now it is in the hands of the High Court and there is no difficulty. Every single thing that any honest person wants in order to work a patent can be got by a very simple, comparatively inexpensive method by applying for a license. It seems to me that it is perfectly ridiculous to have a section for compulsory working in view of the fact that you can apply for a compulsory license under Section 24.

THE CHAIRMAN: I am certain that you will all agree that this discussion will not be complete without our hearing the views of our Honorary Secretary, Mr. Evans-Jackson, on the subject.

MR. J. E. EVANS-JAckson: Mr. Presideni, my Lord, Gentlemen, and Fellow Members-I am quite certain you will all agree with me that the President has made a great mistake and that he ought to have closed the proceedings without calling upon the Honorary Secretary to say anything. At the same time, in the few minutes remaining, I would just like to make one or two remarks on a subject with which I am closely connected. Last year, at the Congress of the Associated Chambers of Commerce in Antwerp, I was able to carry, by a large majority, a vote of the delegates postponing the discussion on compulsory working until this year. At the last meeting of the Associated Chambers held in March last, and I have here to confinm me in. what I say, Mr. Dunwoody, who is the Secretary of the Associated Chambers and Mr. Wright, who is the Secretary of the Birmingham Chamber, viz., that the delegates of the various Chambers went to that Congress pledged as to the way in which their votes were to be tecorded. That, to my mind, is rather an extraordinary sort of business. You have what is called the Associated Chambers of Commerce, meeting in the greatest city in the world, listening to the arguments of the greatest experts on various stbjects that this and other cities can find. The delegates have put before them every argument for and against, I do not care which side it is; but when the discussion is finished the delegates have to hold up their hands in accordance with a decision which has been given probably a month before in their respective Chambers. Mr. Dunwoody, who is the Secretary of the Associated Chambers of Commerce, is here and he will confirm that what I say is correct. Now I ask whether a decision given in a meeting like that is to carry any weight with the authorities. The decision is given before the arguments are placed before the delegates.

Now, Gentlemen, on this question of compulsory working 
I suppose it will probably be admitted that I have possibly some small professional experience (over thirty years); but I am putting myself tonight in the position of a business man and a man representing, to some extent, the commerce of England; and $I$ am going to ask you this question, and it is a serious one: Whether Great Britain will benefit by the fact that John Smith, an inventor of a horseshoe, the most meritorious and extremely beneficial horseshoe, and who applies for a patent in London, also applies for patents in forty foreign countries, Germany, France, Belgium, Austria, etc. Is it to the advantage of British commerce that that inventor should be compelled to erect forty factories, one in each of forty foreign countries, to make those horseshoes, or is it more to the advantage of this country that he should manufacture the whole lot here at a cheaper rate and send them abroad?

Now, what is my point there? Of course, you do not know. I am going to put it to you. We are going to compel John Schmidt, a German, who has invented a horseshoe in Berlin, and who has taken out a patent in forty countries, including Great Britain, to build a factory here to make those horseshoes. The thing is purely illustrative of the argument as to manufacturing certain articles. We compel one foreigner to mantfacture in this country the quantity required for use of this country alone, while welay ourselves open by retaliation on the part of foreign Governments to be compelled to manufacture in forty countries the invention which has been thought out in this country.

Now, the point which appears to me to be essential is whether it is beneficial to secure the wages to the working class in mantfacturing one foreign invention here and to lose the wages (which would otherwise be paid here) by being compelled to manufacture goods to meet the requirement of forty countries of a British invention abroad. Now, put it purely as a commercial and a business proposition: Ask Mr. Gordon Selfridge or Mr. Gamage or any thoughtful business men and see what they will say to you. I imagine the reply would be that the proposition was a most foolish one.

Well, I should like to say in conclusion that this question, if it is going to be carried any further with us, means retaliation. I said that at the Chamber of Commerce the other day. It has met with retaliation already. What was the effect of passing that Compuslory Working Act? The United States of America never had any compulsory working: Germany had. The moment we passed that Act in England, Germany approached the United States and completed a treaty whereby working in the United States was equivalent to working in Germany, and working in Germany was equivalent to working in the United States. Since then a similar treaty has been enacted between Germany and Switzerland, Germany and Italy, Germany and Spain, and Germany and Sweden. Now take Switzerland. Up to the time that we passed that Act here, working in any country was working in Switzerland. Now a British inventor must work his invention in Switzerland, otherwise his patent is liable to be revoked. Previous to that Act all he had to do was to work in Great Britain. Now we have under that Act no power whatever to negotiate with the United States, with Germany or with Italy and get equal conditions with those which have already been arranged and signed and sealed between the United States and Germany and other countries. I think it is neither more nor less than monstrous that Great Britain is not in a position to negotiate on reciprocal terms with other countries and say, "If you will let our people off working in your countries we will let your people off working here."

Then the last word I have to say is this, that, if any further change is made in our law at all, it should be this, that a petitioner should be compelled to go to the Comptroller and say, "I am prepared to work this patent in Great Britain, and that is the ground on which $I$ ask that the patent shall be revoked if it is not already worked." And I should insist that in any rules or in any laws which are made in future no foreigner should come here and be allowed to revoke a patent solely for the purpose of dumping foreign goods into Great Britain.

MR.' OLIVER IMRAY: Gentlemen, I just want to say this one word. I ought not to speak a second time, but it has come to my knowledge only today that the German people, in view of the Manchester Chamber of Commerce agitation for a more drastic interpretation of the present law as to the working, have approached their Government to retaliate. That is all I want to say.

MR. W. TEMPLE FRANKS, C.B., Comptroller-General of Patents: Mr. Chairman, Lord Moulton, and Gentlemen-It is my great pleasure and privilege to ask you to drink a toast which is not upon the list, but which none the less I think you will drink with every kind of enthusiasm and honor, and that is the toast of our Chairman tonight, Sir George Wyatt Truscott. On behalf of the guests I should like to offer him my most grateful thanks for the delightful hospitality which this Club has afforded to us and for the opportunities given us of hearing one of the most interesting debates.

As the unhappy man who has to decide the cases which have been so much discussed tonight, and whose only pleasure in that position is to hear the eloquence of my old friend, $\mathrm{Mr}$. Walter, and of Mr. Colefax, and Mr. Gray, I have not been able to take part in the debate, but none the less it has been a debate fraught with the greatest interest to me and one which may have real educational influence upon those who may have in the future to decide what amendments, if any, should be made to the present Act. Whether it will be possible at any time to bring in an amending Bill to the present Act lies, I think, with my friend, Sir George Croydon Marks and his party. At present it is almost impossible to introduce legislation of that kind.

I can assure you that the substance of what has fallen from the speakers tonight, and especially from Lord Moulton, whose genius has left its mark upon all the legislation and practice in respect of industrial property in this country, will certainly be conveyed by me to the Board of Trade. The only thing I feel it possible to say in this connection is this, that I hope if any amendment is made that it will not throw further and more arduous duties upon me. The problems I have to decide at present are quite complicated enough for me and for my poor intellect; and when I confide to you that the Copyright Act has been entrusted to my care, you will understand that my time is sufficiently taken up with difficult legal problems.

If I intervene at all in the discussion, it is only to say that there may be, perhaps, between the contending parties a happy line of peace, and that is this: I understand the supporters of the present Section lament the fact that the applications for revocation of patents have enormously falien off, and maintain in consequence that the Section is a dead letter. In that case the opponents of the Section ought really to be satisfied. On the other hand, I think it is quite possible that the mere presence of the Section, even in its present form, does assist to bring about a result which many most earnestly desire, and that is a greater willingness on the part of patentees to grant licenses with regard to patents. I only throw that out as a possibility. In any case, the debate, if I may venture to say so, has been to me of the most interesting and delightful kind, and I can only convey again my thanks to the President for allowing me the privilege of being here. I am sure I am speaking on behalf of all the other visitors here, and I ask you to drink with the greatest enthusiasm and cordiality the health of our Chairman.'

THE chatrman: My Lord and Gentlemen-When Mr. Temple Franks first rose and addressed us I came to the conclusion that he was introducing entirely foreign matter and that I should have to call him to order; but he went on to redeem the situation and to make a very pretty contribution to our discussion here tonight. I should like to thank him on behalf of the Club for the compliment of appreciation which he has paid to us and which I very gratefully acknowledge. 